\title{
The effect of straw compost on nutrient uptake and yield of rice in newly opened and intensive lowland
}

\author{
Ismon Lenin ${ }^{1 *}$, Widia Siska², and Eka Mirnia ${ }^{1}$ \\ ${ }^{1}$ West Sumatra Assessment Institute for Agricultural Technology, West Sumatra, Indonesia \\ ${ }^{2}$ Indonesian Center for Agricultural Technology Assessment and Development, Bogor, Indonesia
}

\begin{abstract}
The objectives of this research were to determine the effect of natural materials added to the rice straw fermentation process; and to find the best formula for organic fertilizers to increase nutrient uptake, growth, and rice grain yield in newly opened and intensive lowland. The research was conducted at West Sumatra AIAT's laboratory and lowlands at Dharmasraya Regency, West Sumatra Province, Indonesia from July to December 2017. The first research included three formulas of organic fertilizers and the second included six treatments produced from the first research. The results showed that increasing amount of titonia from $200 \mathrm{~kg}$ to $400 \mathrm{~kg}$ and rock phosphate from $5 \mathrm{~kg}$ to $20 \mathrm{~kg}$ per ton of rice straw increased compost's nitrogen and phosphorus content of the compost from $1.22 \%$ to $1.36 \%$, and from $0.75 \%$ to $1.68 \%$ respectively. Application of compost without inorganic fertilizers in newly opened lowland decreased $23 \%$ of yield and increased $4.7 \%$ yield when combined with inorganic fertilizers. The combined application of organic and inorganic fertilizers increased $10-12 \%$ yield and decreased $10 \%$ of yield without inorganic fertilizers in intensive lowland. Application of organic fertilizer without inorganic fertilizers not significantly influenced the growth. Combination of organic and inorganic fertilizers is the best way to increase lowland rice yield.
\end{abstract}

\section{Introduction}

The inefficiency of inorganic fertilizers for paddy rice is not balanced conformable by increased rice production, meaning that the increase in fertilizer use is not proportional to the balanced increase in rice yields [1]. One of the causes of the increase of inorganic fertilizers use is the significant reduction in soil organic matter as a result of minimum land and resource management [2]. This happens mostly in the intensively used land, both in lowland or upland [3].

Almost $90 \%$ of the lowlands in Indonesia have low organic matter content with $\mathrm{C}$ organic less than $2.0 \%$ which causes low fertilization efficiency and effectiveness and low rice yields [4]. In West Sumatra Province, Indonesia, about $60 \%$ of the lowlands are less

* Corresponding author: ismonlenin@yahoo.com 
than $2.0 \%$ C-organic [5]. The low content of organic matter is not only found in the lowlands but also the highlands. Suridikarta et al. [6] found that intensive use of upland for 12 years reduced the organic matter drastically from $6.80 \%$ to $1.79 \%$. On the other hand, farmers tend to burn rice straw and use inorganic fertilizers excessively for their crops [1], [7].

Research in several countries showed that the use of organic matter (rice straw) had a positive effect on the physical, chemical, and biological aspects of the lowlands [3]. Rice straw is the main source of potassium $(\mathrm{K})$ and silica $(\mathrm{Si})$ so the re-application of this material can slow down the decrease of K and Si in the soil [8]. Adiningsih [9], found that the application of 5 tonnes of rice straw per hectare per planting season continuously for four planting seasons contributed about $170 \mathrm{~kg} \mathrm{~K}, 160 \mathrm{~kg} \mathrm{Mg}, 200 \mathrm{~kg} \mathrm{Si}$, and 1.7 tonnes of $\mathrm{C}$-organic to the soil. In newly opened lowland, the application of rice straw compost as much as $2.5 \mathrm{t} / \mathrm{ha}$ could substitute $50 \% \mathrm{KCl}$ fertilizer from $75 \mathrm{~kg} \mathrm{KCl} / \mathrm{ha} \mathrm{[10].}$

To anticipate fertilizer expensive prices and reduce energy for fertilizer production, now is the time to utilize abundant local resources such as crop straw, green manure, and household waste as plant fertilizers with the right process. It can also answer the increasing demand for organic fertilizers as well as organic agricultural products. The technology of production and applications of organic fertilizers to preserve land resources and environmental sustainability, reduce dependence on inorganic fertilizers, and support the "Go Organic 2010" program of the Indonesian Ministry of Agriculture, are currently strongly needed.

The objectives of this study were: (1) to determine the effect of natural materials (titonia, rock phosphate, dolomite, and rice husk) added to the rice straw fermentation process to the organic fertilizers, especially in terms of nitrogen, phosphorus, potassium, and magnesium content; and (2) To find the best formula for organic fertilizers to increase, nutrient uptake, growth and grain yield of lowland rice in newly opened and intensive lowland.

\section{Material and methods}

\subsection{Production of organic fertilizers}

This research was carried out from July to December 2017, started with the production and propagation of Trichorderma harzianum in the West Sumatra AIAT's laboratory for one month (July 2017). Trichorderma harzianum was selected as a decomposer because of its good ability to decompose cellulose and hemi cellulose. Trichorderma harzianum was propagated on PDA media for three days, then transferred to sterile rice media for 10 days with shaken every three days. Media with full green sporangium was dried and ready to be used as T. harzianum spores. The organic fertilizer formula was maintained through the addition of high-nutrient natural materials in the composting process. The natural materials used were titonia (source of $\mathrm{N}$ and $\mathrm{K}$ ), phosphate rock (source of $\mathrm{P}$ ), and dolomite (source of $\mathrm{Ca}$ and $\mathrm{Mg}$ ). The nutritional content of the three materials and rice straw is presented in Table 1. 
Table 1. The average macronutrients and C-organic content of the main ingredient of organic fertilizer.

\begin{tabular}{|l|l|l|l|l|l|l|}
\hline \multirow{2}{*}{\multicolumn{1}{|c|}{ Materials }} & \multicolumn{7}{|c|}{ Nutritional content (\%) } \\
\cline { 2 - 7 } & $\mathbf{C}$ & \multicolumn{1}{|c|}{$\mathbf{N}$} & \multicolumn{1}{|c|}{$\mathbf{P}$} & $\mathbf{K}$ & $\mathbf{C a}$ & $\mathbf{M g}$ \\
\hline Titonia & 5.46 & 2.91 & 0.36 & 4.81 & 1.69 & 0.25 \\
\hline Rice straw & 4.92 & 0.46 & 0.13 & 2.02 & 0.33 & 0.16 \\
\hline Rock phosphate & - & - & 17.27 & - & - & - \\
\hline Dolomite & - & - & - & - & 12.98 & 0.60 \\
\hline
\end{tabular}

Some comparisons between the main treatment materials, titonia, rock phosphate, and dolomite are presented in Table 2. The treatments were arranged in a completely randomized block design with five replications.

Table 2. The formula of rice straw and market waste in the production of organic fertilizers (composts).

\begin{tabular}{|c|c|c|r|r|}
\hline Treatment & $\begin{array}{c}\text { Rice Straw } \\
(\mathbf{k g})\end{array}$ & \multicolumn{1}{|c|}{$\begin{array}{c}\text { Titonia } \\
(\mathbf{k g})\end{array}$} & $\begin{array}{c}\text { Rock Phosphate } \\
(\mathbf{k g})\end{array}$ & \multicolumn{2}{|c|}{$\begin{array}{c}\text { Dolomite } \\
(\mathbf{k g})\end{array}$} \\
\hline Compost 1 & 1.000 & 400 & 5 & 20 \\
\hline Compost 2 & 1.000 & 300 & 10 & 15 \\
\hline Compost 3 & 1.000 & 200 & 20 & 5 \\
\hline
\end{tabular}

Rice straw and titonia were chopped to a length of $\pm 5 \mathrm{~cm}$. The rock phosphate and dolomite were ground and sieved with a $2 \mathrm{~mm}$ mesh. Rice husk ash used as much as 20 $\mathrm{kg} / 1,000 \mathrm{~kg}$ of the main material. The main and additional materials were stirred completely, then composted using T. harzianum. The variables measured for each organic fertilizer's formula were: (1) the nutritional content of main and additional materials, (2) Corganic content, (3) water content of organic fertilizers, (4) macronutrients $(\mathrm{N}, \mathrm{P}, \mathrm{K}, \mathrm{Ca}$, and $\mathrm{Mg}$ ) content, (5) metal $(\mathrm{Pb})$ content, and (6) compost's maturity level based on $\mathrm{C} / \mathrm{N}$ values.

\subsection{Application of organic fertilizers}

Organic fertilizers produced from the first research results were tested in the newly opened and intensive lowlands in Dharmasraya Regency, West Sumatra Province, Indonesia. The study was conducted from August to December 2017. Three kinds of organic fertilizers from the preliminary research at a dose of $2.5 \mathrm{t} / \mathrm{ha}$ were tested for their effects on soil chemistry, nutrient uptake, growth, and yield of lowland rice. Three treatments were used for comparison, i.e without compost, without inorganic fertilizer, and with compost $5 \mathrm{t} / \mathrm{ha}$, and without inorganic fertilizer and with compost $10 \mathrm{t} / \mathrm{ha}$. The six treatments were tested using a completely randomized block design with three replications.

The seedlings of IR-66 variety were transplanted at 15-20 days at the rice field with 2-3 seedlings per hole and a planting size of $20 \times 20 \mathrm{~cm}$. Nitrogen fertilizer with a dose of 50 $\mathrm{kg}$ Urea/ha was given for the first time 10 days after planting (DAT). The next $45 \mathrm{~kg} / \mathrm{ha}$ Urea fertilizer was applied based on the Leaf Color Index (LCI). Nitrogen fertilization was applied three times in intensive lowlands and four times in newly opened lowlands. Phosphorus and potassium fertilizers dosage were determined based on the results of soil analysis using $25 \% \mathrm{HCl}$ extract. Phosphorus fertilizer was spread at the planting date and potassium fertilizer was applied twice (at the fast vegetative growth and the maximum seedling stage). The doses of phosphorus and potassium fertilization in the newly opened lowlands were $112.5 \mathrm{~kg} \mathrm{SP}-36$ and $100 \mathrm{~kg} \mathrm{KCl} / \mathrm{ha}$ and in the intensive lowlands were $50 \mathrm{~kg}$ $\mathrm{SP}-36$ and $50 \mathrm{~kg} \mathrm{KCl} / \mathrm{ha}$. 
"Lado-21" technology was implemented to protect rice crops from iron toxicity, based on previous research [11]. Lado-21 is the specific management for high iron content in lowland mineral soils. The Lado-21 technology application in the field started from the beginning, such as crops were not irrigated from planting date to active tillers stage (21-30 DAP), but the land water was regulated according to field capacity. This condition allows crop roots to grow well so they can absorb nutrients optimally. Rice plants were irrigated at or after 30 DAP, and aerob moisture regime were arranged for every two weeks.

The lowland rice crops were hand weeded manually. Pests and diseases were controlled using IPT (Integrated Pests Management) concepts. In this research, pesticide Saturn-D (20 $\mathrm{kg} / \mathrm{ha})$ and Carbofuran $(20 \mathrm{~kg} / \mathrm{ha})$ were only applied at the planting date. The variable measured in this field research included: (1) initial soil analysis, (2) plant growth (plant height and trubus dry weight), (3) nutrients ( $\mathrm{N}, \mathrm{P}, \mathrm{K}, \mathrm{Ca}$, dan $\mathrm{Mg}$ ) uptake, (4) yield components, (5) yield/ha, and (6) farm economic analysis.

\section{Results and discussion}

\subsection{Production of organic fertilizers}

The results showed that the use of Titonia in the composting process increased the nitrogen and potassium content. The higher the Titonia dose, the higher the nitrogen and potassium content in the compost. The increase in Titonia from $200 \mathrm{~kg}$ to $400 \mathrm{~kg}$ per ton of rice straw increased the nitrogen content from $1.22 \%$ to $1.36 \%$ as well as increased the potassium content from $3.17 \%$ to $3.46 \%$ in the compost. Furthermore, increasing the dosage of rock phosphate from $5 \mathrm{~kg}$ to $20 \mathrm{~kg}$ per ton of rice straw increased the phosphorus content in the compost from $0.75 \%$ to $1.68 \%$. Increasing the use of lime in the composting process from 5 $\mathrm{kg}$ to $20 \mathrm{~kg}$ per ton of rice straw increased the calcium content in the compost from $5.53 \%$ to $6.82 \%$, but did not increase the compost's magnesium content mostly due to the low magnesium lime $(0.60 \%)$.

The acidity level $(\mathrm{pH})$ of organic fertilizer produced was high (more than 8$)$. It was probably caused by the use of lime with the high calcium content. In general, all compost formulas applied in this research produced good organic fertilizers based on the Indonesian National Standard with $\mathrm{Pb}$ and $\mathrm{Cd}$ content below 10 ppm (Table 3).

Table 3. The average macronutrient, $\mathrm{C}$-organic, water capacity $(\mathrm{WC})$, and metal $(\mathrm{Pb})$ content of rice straw organic fertilizers produced

\begin{tabular}{|c|c|c|c|c|c|c|c|c|c|c|c|}
\hline \multirow[t]{2}{*}{ Treatment } & \multirow[t]{2}{*}{ pH } & \multicolumn{6}{|c|}{ Macro nutrient content (\%) } & \multirow[t]{2}{*}{$\mathbf{C} / \mathbf{N}$} & \multirow[t]{2}{*}{$\begin{array}{l}\text { WC } \\
(\%) \\
\end{array}$} & \multicolumn{2}{|c|}{$\begin{array}{c}\text { Metals } \\
\text { (ppm) }\end{array}$} \\
\hline & & $\mathbf{C}$ & $\mathbf{N}$ & $\mathbf{P}$ & $\mathbf{K}$ & $\mathbf{C a}$ & Mg & & & $\mathbf{P b}$ & Cd \\
\hline Compost-1 & 8.80 & 17.45 & 1.36 & 0.75 & 3.46 & 5.53 & 0.38 & 13.22 & 34.1 & Ttd & 4.0 \\
\hline Compost-2 & 8.57 & 15.96 & 1.32 & 0.95 & 3.26 & 6.10 & 0.41 & 11.73 & 32.9 & $\mathrm{Ttd}$ & 4.0 \\
\hline Compost-3 & 8.69 & 15.76 & 1.22 & 1.68 & 3.17 & 6.82 & 0.33 & 12.91 & 36.2 & Ttd & 3. \\
\hline $\begin{array}{l}\text { Technical } \\
\text { Regulations }\end{array}$ & $\begin{array}{l}>4 \\
<8\end{array}$ & $>15$ & & & & & & $12-25$ & $20-35$ & $<50$ & $\begin{array}{c}<1 \\
0\end{array}$ \\
\hline
\end{tabular}

\subsection{Application of organic fertilizers}

The characteristics of newly opened lowland are different from intensive lowland. The intensive lowland has a flow pan layer that is not found in newly opened lowland with porous soil conditions [12]. However, the chemical aspects of these two land typologies are relatively the same. Based on the criteria released by the Soil Research Institute (1983) [13], these two research sites had low $\mathrm{pH}$ with high $\mathrm{Ca}$ and $\mathrm{Mg}$ content, so that the lands needed calcification. The average chemical contents of newly opened lowland and intensive 
lowland were presented in Table 4. The content of C-organic in the newly opened lowland was very low (1.75\%) and low in the intensive lowland $(2.21 \%)$. The total nitrogen content in these two land typologies was also low which were $0.20 \%$ in the newly opened lowland and $0.22 \%$ in the intensive lowland. It showed that nitrogen and organic fertilizers were needed. De Datta (1981) [14] stated that the soil nitrogen content of less than $0.25 \%$ would influence the crops growth.

Table 4. The average chemical contents of newly opened lowland and intensive lowland

\begin{tabular}{|c|c|c|c|}
\hline \multirow{2}{*}{ Parameter } & \multicolumn{2}{|c|}{$\begin{array}{l}\text { Land typologies } \\
\end{array}$} & \multirow[t]{2}{*}{ Method of analysis } \\
\hline & Newly opened & Intensive & \\
\hline $\mathrm{pH}(\mathrm{H} 2 \mathrm{O})$ & 5.99 & 5.74 & $\mathrm{pH}$ meter \\
\hline $\mathrm{pH}(\mathrm{KCl})$ & 5.32 & 4.92 & $\mathrm{pH}$ meter \\
\hline C-Organic (\%) & 1.75 & 2.21 & Kurmis \\
\hline Total N $(\%)$ & 0.20 & 0.22 & Kjedahl \\
\hline Available P (ppm) & 20.00 & 24.75 & Bray I \\
\hline Total P (mg/100g) & 45.87 & 67.29 & $\mathrm{HCl} 25 \%$ \\
\hline Total K (mg/100 g) & 15.93 & 11.21 & $\mathrm{HCl} 25 \%$ \\
\hline $\mathrm{Ca}-\mathrm{ec}(\mathrm{cmol}(+) / \mathrm{kg}$ & 10.14 & 9.32 & N NH4Oac pH 7 \\
\hline Mg-ec (cmol (+)/kg & 1.50 & 1.54 & N NH4Oac pH 7 \\
\hline $\mathrm{K}-\mathrm{ec}(\mathrm{cmol}(+) / \mathrm{kg}$ & 0.31 & 0.16 & N NH4Oac pH 7 \\
\hline $\mathrm{Na}-\mathrm{ec}(\mathrm{cmol}(+) / \mathrm{kg}$ & 2.19 & 1.49 & N NH4Oac pH 7 \\
\hline $\mathrm{CEC}(\mathrm{cmol}(+) / \mathrm{kg})$ & 23.32 & 27.14 & $\begin{array}{l}\text { Number of exchangeable } \\
\text { cation }\end{array}$ \\
\hline Alkalinity (\%) & 60.63 & 45.75 & \\
\hline Al-ec $(\mathrm{cmol}(+) / \mathrm{kg})$ & 3.43 & 2.23 & N NH4Oac pH 7 \\
\hline H-ec $(\mathrm{cmol}(+) / \mathrm{kg})$ & 1.02 & 2.30 & N NH4Oac pH 7 \\
\hline $\mathrm{Cu}(\mathrm{ppm})$ & 6.16 & 4.42 & N NH4Oac pH 7 \\
\hline $\mathrm{Zn}(\mathrm{ppm})$ & 17.23 & 7.59 & N NH4Oac pH 7 \\
\hline $\mathrm{Mn}(\mathrm{ppm})$ & 17.90 & 38.25 & N NH4Oac pH 7 \\
\hline $\mathrm{Fe}(\mathrm{ppm})$ & 630.25 & 513.34 & N NH4Oac pH 7 \\
\hline
\end{tabular}

Total phosphorus $(25 \% \mathrm{HCl})$ of soil was high but total potassium $(25 \% \mathrm{HCl})$ was relatively low. The application of harvested rice straw will contribute high enough potassium to the soil. Rice straw can be an important source of potassium for the lowlands, because about $80 \%$ of the potassium absorbed by crops is left in the straw [15]. Therefore, rice straw has a high potential for substituting inorganic potassium fertilizers when it is applied either as a fresh form or its compost form. For potential medium potassium content $(10-20 \mathrm{mg} / 100 \mathrm{~g}$ soil) in lowlands, 2 tons of rice straw per hectare is sufficient [2].The Fe content in the lowlands of the research site was high which can cause iron toxicity for lowland planted rice. In this research, the implementation of Lado-21 technology had protected lowland rice crops from iron toxicity [10].

\subsection{Macronutrients uptake}

In the newly opened lowland, the rice crops applied with compost combined with inorganic fertilizers (Compost-1, Compost-2, and Compost-3) have performed a nitrogen deficiency at 45 days after planting. On the other hand, the rice crops still grew well at the same time in the intensive lowland, showing that the crops did not experience nitrogen deficiency (Table 5). 
Table 5. The average macronutrients ( $, \mathrm{P}, \mathrm{K}, \mathrm{Ca}$, and $\mathrm{Mg}$ ) uptake of lowland rice at 45 days after planting with some treatments of organic fertilizers in the newly opened and the intensive lowlands

\begin{tabular}{|c|c|c|c|c|c|}
\hline \multirow{2}{*}{ Treatments } & \multicolumn{5}{|c|}{ Macro nutrient content (\%) } \\
\cline { 2 - 6 } & $\mathbf{N}$ & $\mathbf{P}$ & $\mathbf{K}$ & $\mathbf{C a}$ & Mg \\
\hline \multicolumn{7}{|c|}{ Newly opened lowland } \\
\hline Compost-1 & 0.68 & 0.18 & 2.02 & 0.31 & 0.14 \\
\hline Compost-2 & 0.69 & 0.17 & 2.69 & 0.55 & 0.12 \\
\hline Compost-3 & 0.67 & 0.19 & 2.04 & 0.27 & 0.12 \\
\hline Zero Compost & 0.77 & 0.16 & 2.32 & 0.34 & 0.14 \\
\hline 5 t/ha Compost & 0.55 & 0.14 & 2.76 & 0.28 & 0.12 \\
\hline 10 t/ha Compost & 0.67 & 0.18 & 2.13 & 0.23 & 0.12 \\
\hline \multicolumn{7}{|c|}{ Intensive lowland } \\
\hline Compost-1 & 1.09 & 0.12 & 1.77 & 0.72 & 0.15 \\
\hline Compost-2 & 1.20 & 0.12 & 1.76 & 1.24 & 0.17 \\
\hline Compost-3 & 1.16 & 0.16 & 1.69 & 0.35 & 0.15 \\
\hline Zero Compost & 1.27 & 0.14 & 1.35 & 0.92 & 0.15 \\
\hline 5 t/ha Compost & 1.17 & 0.15 & 1.95 & 0.27 & 0.16 \\
\hline 10 t/ha Compost & 1.15 & 0.14 & 1.87 & 0.36 & 0.16 \\
\hline $\begin{array}{c}\text { The level of nutrient } \\
\text { sufficiency }\end{array}$ & $1.0-2.5$ & $0.1-0.2$ & $1.0-2.0$ & $0.2-0.6$ & $0.15-0.30$ \\
\hline
\end{tabular}

Plant nitrogen deficiency is caused by the low availability of nutrients in the soil. Nitrogen is a mobile element so it can be quickly lost due to fotilization or leaching. In the newly opened lowland, the leaching process is faster than in the intensive lowland, because the newly opened lowland has more porous soil conditions and the soil does not yet have a flow pan. Mobile nutrients such as nitrogen, potassium, calcium, and magnesium will quickly disappear or be far from the root crop zone. It causes the crops nutrient deficiency.

The phosphorus, potassium, and calcium uptakes of lowland rice, both in the newly opened lowland or intensive lowland, were more than sufficient (Table 5). On the other hand, the magnesium uptake of lowland rice in the newly opened lowland, was below the sufficient level but it was sufficient in the intensive lowland. The insufficiency of magnesium in the newly opened lowland was maybe caused by the leaching process while rice crops being irrigated.

\subsection{The rice crops growth}

The statistical analysis results showed that the plant height and number of maximum tillers were significantly affected by the treatments. Application of organic fertilizers without inorganic fertilizers caused shorter crops with a limited number of tillers. Increasing the compost dosage from 5 to $10 \mathrm{t} /$ ha increased the number of tillers, but was still far below the number of tillers in the combination of inorganic fertilizers and compost treatment (Table 6).

The formula of compost (Compost-1, Compost-2, and Compost-3) treatment did not significantly influence the number of productive tillers of lowland rice. However, the application of compost without inorganic fertilizers significantly decreased the number of productive tillers, both in the newly opened lowland and in the intensive lowland. 
Table 6. The average plant height at harvesting time, the maximum, and the productive number of tillers of lowland rice with some organic fertilizers treatments in the newly opened and the intensive lowland.

\begin{tabular}{|c|c|c|c|c|c|c|}
\hline \multirow{3}{*}{ Treatments } & \multicolumn{2}{|c|}{$\begin{array}{c}\text { Plant height at } \\
\text { harvesting time (cm) }\end{array}$} & \multicolumn{2}{c|}{$\begin{array}{c}\text { Number of maximum } \\
\text { tillers per cluster }\end{array}$} & \multicolumn{2}{c|}{$\begin{array}{c}\text { Number of productive } \\
\text { tillers per cluster }\end{array}$} \\
\cline { 2 - 7 } & $\begin{array}{c}\text { Newly } \\
\text { opened } \\
\text { lowland }\end{array}$ & $\begin{array}{c}\text { Intensive } \\
\text { lowland }\end{array}$ & $\begin{array}{c}\text { Newly } \\
\text { opened } \\
\text { lowland }\end{array}$ & $\begin{array}{c}\text { Intensive } \\
\text { lowland }\end{array}$ & $\begin{array}{c}\text { Newly } \\
\text { opened } \\
\text { lowland }\end{array}$ & $\begin{array}{c}\text { Intensive } \\
\text { lowland }\end{array}$ \\
\hline Compost-1 & $80.67 \mathrm{a}$ & $84.27 \mathrm{ab}$ & $20.6 \mathrm{ab}$ & $19.1 \mathrm{a}$ & $12.93 \mathrm{a}$ & $11.00 \mathrm{ab}$ \\
\hline Compost-2 & $81.40 \mathrm{a}$ & $82.80 \mathrm{bc}$ & $22.5 \mathrm{a}$ & $15.8 \mathrm{bc}$ & $11.87 \mathrm{ab}$ & $10.40 \mathrm{bc}$ \\
\hline Compost-3 & $82.80 \mathrm{a}$ & $87.33 \mathrm{a}$ & $21.6 \mathrm{a}$ & $20.0 \mathrm{a}$ & $12.40 \mathrm{a}$ & $11.93 \mathrm{a}$ \\
\hline Zero Compost & $81.13 \mathrm{a}$ & $84.13 \mathrm{ab}$ & $18.2 \mathrm{ab}$ & $17.6 \mathrm{ab}$ & $11.13 \mathrm{bc}$ & $9.93 \mathrm{bc}$ \\
\hline $5 \mathrm{t} / \mathrm{ha}$ Compost & $75.33 \mathrm{~b}$ & $80.13 \mathrm{c}$ & $12.8 \mathrm{c}$ & $14.0 \mathrm{c}$ & $10.33 \mathrm{c}$ & $9.60 \mathrm{c}$ \\
\hline $10 \mathrm{t} / \mathrm{ha}$ Compost & $75.33 \mathrm{~b}$ & $79.80 \mathrm{c}$ & $16.5 \mathrm{bc}$ & $14.7 \mathrm{bc}$ & $11.40 \mathrm{bc}$ & $9.20 \mathrm{c}$ \\
\hline
\end{tabular}

The numbers followed by the same letter at the same column are significantly different at 0.05 DNMRT level.

Application of compost to the newly opened lowland and intensive lowland significantly affected the lowland rice yield components, except for panicle length. In the newly opened lowland, the highest number of grains (123 grains) was gained in the treatment of 10 ton compost without inorganic fertilizers per hectare and the lowest of its (104 grains) was produced in the treatment of 5 ton compost per hectare without inorganic fertilizers. The average empty rice grains in the newly opened lowland were high for all treatments $(31.60-37.66 \%)$. The application of compost significantly increased the number of grains and decreased the number of empty grains. The highest grain weight was obtained in the Compost-3 treatment (10 t/ha compost plus inorganic fertilizers) but was not significantly different from the treatment without compost and 10 tons compost per hectare without inorganic fertilizers (Table 7).

Table 7. The average yield components of lowland rice with some organic fertilizer treatments in the newly opened and the intensive lowlands.

\begin{tabular}{|c|c|c|c|c|c|c|c|c|}
\hline & \multicolumn{2}{|c|}{$\begin{array}{c}\text { Panicle length (cm) } \\
\text { Treatments }\end{array}$} & \multicolumn{2}{|c|}{$\begin{array}{c}\text { Number of grains per } \\
\text { panicle }\end{array}$} & \multicolumn{2}{c|}{$\begin{array}{c}\text { The percentage of } \\
\text { empty grains }\end{array}$} & \multicolumn{2}{|c|}{$\begin{array}{c}\text { Weight of 1000 } \\
\text { grains }(\mathbf{g})\end{array}$} \\
\cline { 2 - 10 } & $\begin{array}{c}\text { Newly } \\
\text { opened } \\
\text { lowland }\end{array}$ & $\begin{array}{c}\text { Intensive } \\
\text { lowland }\end{array}$ & $\begin{array}{c}\text { Newly } \\
\text { opened } \\
\text { lowland }\end{array}$ & $\begin{array}{c}\text { Intensive } \\
\text { lowland }\end{array}$ & $\begin{array}{c}\text { Newly } \\
\text { opened } \\
\text { lowland }\end{array}$ & $\begin{array}{c}\text { Intensiv } \\
\text { e } \\
\text { lowland }\end{array}$ & $\begin{array}{c}\text { Newly } \\
\text { opened } \\
\text { lowland }\end{array}$ & $\begin{array}{c}\text { Intensive } \\
\text { lowland }\end{array}$ \\
\hline Compost-1 & $22.82 \mathrm{a}$ & $23.57 \mathrm{a}$ & $117.87 \mathrm{ab}$ & $137.30 \mathrm{c}$ & $31.60 \mathrm{~b}$ & $34.43 \mathrm{ab}$ & $22.42 \mathrm{~b}$ & $24.84 \mathrm{ab}$ \\
\hline Compost-2 & $22.58 \mathrm{a}$ & $23.83 \mathrm{a}$ & $113.47 \mathrm{ab}$ & $141.53 \mathrm{ab}$ & $36.08 \mathrm{a}$ & $37.17 \mathrm{a}$ & $23.54 \mathrm{~b}$ & $24.37 \mathrm{abc}$ \\
\hline Compost-3 & $23.02 \mathrm{a}$ & $23.47 \mathrm{a}$ & $110.07 \mathrm{bc}$ & $149.30 \mathrm{a}$ & $31.65 \mathrm{~b}$ & $33.34 \mathrm{ab}$ & $25.39 \mathrm{a}$ & $25.43 \mathrm{a}$ \\
\hline Zero Compost & $23.72 \mathrm{a}$ & $24.33 \mathrm{a}$ & $119.87 \mathrm{ab}$ & $132.30 \mathrm{c}$ & $35.19 \mathrm{a}$ & $33.53 \mathrm{ab}$ & $23.88 \mathrm{ab}$ & $25.38 \mathrm{a}$ \\
\hline $5 \mathrm{t} / \mathrm{ha}$ Compost & $22.83 \mathrm{a}$ & $23.93 \mathrm{a}$ & $103.57 \mathrm{c}$ & $142.30 \mathrm{ab}$ & $35.90 \mathrm{a}$ & $30.09 \mathrm{~b}$ & $24.10 \mathrm{ab}$ & $23.86 \mathrm{bc}$ \\
\hline $10 \mathrm{t} / \mathrm{ha}$ Compost & $22.60 \mathrm{a}$ & $24.37 \mathrm{a}$ & $123.30 \mathrm{a}$ & $140.23 \mathrm{abc}$ & $37.66 \mathrm{a}$ & $33.58 \mathrm{ab}$ & $25.24 \mathrm{a}$ & $23.81 \mathrm{c}$ \\
\hline
\end{tabular}

The numbers followed by the same letter at the same column are significantly different at 0.05 DNMRT level.

In newly opened lowland, the application of compost combined with inorganic fertilizers (Compost-1, Compost-2, and Compost-3) significantly increased lowland rice yield. The highest grain yield ( $4.67 \mathrm{t} / \mathrm{ha}$ ) was gained in Compost-3 treatment. The treatment of Compost-1 was not increasing the rice grain yield compared to the control treatment (Zero Compost); on the other hand, Compost-2 and Compost-3 increased the grain yield of lowland rice by $4.7 \%$ and $5.9 \%$, respectively. The application of 5 tons and 10 tons of compost per hectare without inorganic fertilizers decreased the rice grain yield by about $23 \%$ and $17.5 \%$, respectively. The fact showed that the newly opened lowland required a 
high dosage of organic fertilizers (compost) and should be combined with inorganic fertilizers such as Urea, SP, and $\mathrm{KCl}$ ).

In the intensive lowland, the application of organic fertilizer combined with inorganic fertilizers (Compost-1, Compost-2, and Compost-3 treatments) increased the grain yield of lowland rice by $10 \%, 9 \%$, and $8 \%$, respectively, compared to Zero Compost treatment. The highest grain yield $(5.202 \mathrm{t} / \mathrm{ha})$ was obtained at the Compost-1 treatment and the lowest $(4.278 \mathrm{t} / \mathrm{ha})$ at the treatment of 10 tons compost per hectare without inorganic fertilizers (Table 8). It means that the application of organic fertilizer without inorganic fertilizers in the intensive lowland decreased the grain yield of lowland rice by about $8-10 \%$. On the contrary, the application of organic fertilizer combined with inorganic fertilizers increased the grain yield of lowland rice by about $10 \%$.

Table 8. The average grain yield of rice and its increase in the newly opened and the intensive lowland with some treatments of organic fertilizers (compost).

\begin{tabular}{|c|c|c|c|c|}
\hline \multirow{2}{*}{ Treatments } & \multicolumn{2}{|c|}{ Grain yield (t/ha) } & \multicolumn{2}{c|}{ Yield index } \\
\cline { 2 - 5 } & $\begin{array}{c}\text { Newly opened } \\
\text { lowland }\end{array}$ & $\begin{array}{c}\text { Intensive } \\
\text { lowland }\end{array}$ & $\begin{array}{c}\text { Newly opened } \\
\text { lowland }\end{array}$ & $\begin{array}{c}\text { Intensive } \\
\text { lowland }\end{array}$ \\
\hline Compost-1 & $4.409 \mathrm{a}$ & $5.202 \mathrm{a}$ & 100.0 & 110 \\
\hline Compost-2 & $4.617 \mathrm{a}$ & $5.136 \mathrm{a}$ & 104.7 & 109 \\
\hline Compost-3 & $4.673 \mathrm{a}$ & $5.128 \mathrm{a}$ & 105.9 & 108 \\
\hline Zero Compost & $4.411 \mathrm{a}$ & $4.732 \mathrm{ab}$ & 100.0 & 100 \\
\hline $5 \mathrm{t} / \mathrm{ha}$ Compost & $3.379 \mathrm{~b}$ & $4.297 \mathrm{~b}$ & 76.6 & 91 \\
\hline $10 \mathrm{t} / \mathrm{ha}$ Compost & $3.641 \mathrm{~b}$ & $4.278 \mathrm{~b}$ & 82.5 & 90 \\
\hline
\end{tabular}

The numbers followed by the same letter at the same column are significantly different at 0.05 DNMRT level.

The role of organic fertilizers on rice yield in newly opened lowland was greater than in intensive lowland. The application of organic fertilizer combined with inorganic fertilizers only increased the lowland rice grain yield by about $4.7-5.9 \%$. On the other hand, without inorganic fertilizers, the application of organic fertilizer decreased the grain yield of lowland rice up to $23 \%$.

The application of organic fertilizer without inorganic fertilizers, both in the newly opened lowland and in the intensive lowland, does not significantly influence the lowland rice yield. This means that lowland rice cannot produce the maximum grain yield only with organic fertilizer. The doses of inorganic fertilizers such as Urea, SP, and $\mathrm{KCl}$ applied in this research were based on soil analysis and the needs of the crops. Although organic materials are an important component in the nutrients cycle in agro-ecosystems, the application of inorganic fertilizers must be applied for lowland rice. Some scientists, like Dobermann [16], strongly believe that the production of cereal crops nationally, regionally, and in the world, depends on the availability and application of inorganic fertilizers, nowadays and in the future.

The role of materials in the first planting season of this experimental results on the growth, nutrient uptake, and yield of lowland rice is still very limited. According to Syam [17], the effect of organic matter on soil quality and crop yields will be seen after being applied continuously for several years. Doberman [16] stated that several old studies related to lowland and upland farming systems showed that continuous application of organic materials had not increased crop yields significantly compared to good crop management with balanced fertilizers treatment. 


\section{Conclusions}

Compost without inorganic fertilizers decreased the grain yield of lowland rice by $23 \%$. However, the application of compost combined with inorganic fertilizer increased the grain yield by about $4.7 \%$. The quality of compost produced in this research met the SNI standard with low metal content (unidentified $\mathrm{Pb}$ and $\mathrm{Cd}$ below $4 \mathrm{ppm}$ ). In the newly opened lowland, the effect of inorganic fertilizers was higher than organic fertilizer. Application of compost 1 combined with inorganic fertilizers $(50 \mathrm{~kg} \mathrm{SP} 36+50 \mathrm{~kg} \mathrm{KCl}+150 \mathrm{~kg} \mathrm{Urea} / \mathrm{ha})$ is the best way to increase rice yield as well as rice production in the intensive lowlands, and for the newly opened rice fields, the best combination is compost 3 with inorganic fertilizers $(112.5 \mathrm{~kg} \mathrm{SP} 36+100 \mathrm{~kg} \mathrm{KCl}+150 \mathrm{~kg} \mathrm{Urea} / \mathrm{ha})$.

\section{References}

1. J. A. Adiningsih, Efforts in increasing rice productivity through balanced fertilization, A paper presented in the Meeting on Balanced Fertilization Technology, 14 December 2005, Padang, Indonesia (2005)

2. A. K. Makarim, I. N. Widiarta, S. Henrasih, S. Abdulrachman, A technical guide on nutrients management and pests and diseases control management for integrated lowland rice management (Department of Agriculture, Jakarta, 2003)

3. L. Gunarto, P. Lestari, H. Supadmo, A.R. Marzuki, J. Penelit. Pertan. 21, 2, 1-9 (2002)

4. J. A. Adiningsih, The role of organic fertilizers in supporting the improvement of agricultural land productivity, A paper presented in the Meeting on Balanced Fertilization Technology, 14 December 2005, Padang, Indonesia (2005)

5. Ismon L, S. Abdullah, Burbey, E. Mawardy, Samsudarman, A guide for specific location fertilization technology in West Sumatra (West Sumatra Provincial Government of Agriculture, Padang, 2007)

6. D. A. Suriadikarta, T. Prihatini, D. Setyorini, W. Hartatik, The technology on the soil organic materials management. In Adimiharja, A. and Mappaona (eds.). The Technology for Upland Management Towards Productive and Environmental Safe of Agriculture (The Central Research and Development for Soil and Agro-climate, 2005)

7. Diperta West Sumatra, The program to increase the productivity of food crops and horticulture in West Sumatra, A paper presented in the Workshop on Management of Newly Opened Lowland in BatangHari Irrigated Area in Dharmasraya, 4-5 December 2008, West Sumatra, Indonesia (2008)

8. A. Wiharjaka, K. Idris, A. Rachim, S. Partoharjono, J. Penelit. Pertan. 21, 1, 1-63 (2002)

9. J.A. Adiningsih, Effect of some factors on the availability of soil potassium in lowland at Sukabumi and Bogor (Bogor Agricultural Institute, Bogor, 1994)

10. Ismon L, P. Yufdy, J. Agric. Res. Dev. 14, 3, 217-230 (2011)

11. Ismon L, Azwir, Response of lowland rice to fertilization and change of management of the Ultisol (TypicHapludults) newly opened lowland in two depths of soil tillage, (2011)

12. B. Prasetyo, The genesis of newly opened lowland. In F. Agus, Whyunto, D. Santoso (eds.), The Newly Opened Lowland Soil (The Agricultural Land Resources Institute, Bogor, 2007)

13. The Soil Research Institute, Term of reference soil capability survey, The Central Research Institute for Soil - Research Project Supporting Transmigration (P3MT), Bogor (1983)

14. S.K. De Datta, Principles and practices of rice production (John Wiley and Sons, New York, 1981) 
15. Bijay-Singh, Y.H. Shan, S.E. Johnson-Beebout, Yadvinder-Singh, R.J. Buresh, Adv. Agron. 98, 8, 117-199, doi: 10.1016/S0065-2113(08)00203-4 (2008)

16. A. Dobermann, Can organic agriculture or SRI feed Asia? Unpublished paper for internal use, IRRI, Los Banos, Philippines (2007)

17. S. Syam, Organic rice and the need for increasing rice production (The Food Crops Technology, CRIFC, Bogor, 2008) 